\author{
Ołeksandra Hul* \\ Uniwersytet imienia Borysa Hrinczenki w Kijowie (Ukraina) \\ https://orcid.org/0000-0003-0170-8150
}

\title{
Chinese avant-garde poetry in times of mind, mayhem and money through the interpretation of Maghiel van Crevel
}

[rec. Maghiel van Crevel, Chinese poetry in times of mind, mayhem and money, 2008, ISBN: 978-90-47-44273-8; https://doi.org/10.1163/ej.9789004163829.I-518]

Abstract: The article is written in the form of a book review. It tells about the Chinese avant-garde poetry as a tendency in the literature of the turn of the 20th and the 21st centuries. We are acquainted with the contemporary poetry through the eyes of Maghiel van Crevel, who, being a famous professor-sinologist, describes the lyrical vanguard with all its peculiarities. In his book he shows the real background of the exile poetry. The reader can not only see the positive sides of the modern poetry, but can also understand the controversial nature of the "Misty poetry" in its entirety. The article gives a brief history of contemporary poetry. It covers the period of forbidden underground poetry during the times of cultural revolution, and shows all the transformation stages of the Chinese avant-garde in literature. In the article we can trace the attitude of Maghiel van Crevel towards the Western art influence on the Chinese culture and poetry. He skillfully expresses his thoughts and feelings by using the words of the others and citing the leading Chinese literary critics.

Ołeksandra Grygorivna Hul - mgr, sinolog i anglistka, doktorantka Katedry Literatury Ukraińskiej im. Borisa Hrinczenki w Kijowie (Ukraina). 
The most interesting thing is that the author of the book focuses his attention on the poets who do not belong to the key representatives of the poetic avant-garde. This helps the reader to understand that a poet is an ordinary person and can write in a simple manner using the colloquial speech just to be closer to other people.

The key aim and goals of the Article is to become a vivid literary guide to the avant-garde poetry environment and to give some clues to the reasons of the poetry in exile.

Key words: Maghiel van Crevel, Chinese avant-garde, Misty poetry, poets in exile, Xi Chuan, Han Dong and Yu Jian, Yin Lichuan, Shen Haobo, Yan Jun

\section{Chińska poezja awangardowa czasów rozumu, bezprawia i pieniędzy w interpretacji Maghiela van Crevela}

Streszczenie: W artykule mowa jest o chińskiej poezji awangardowej, rozumianej jako trend w literaturze wieku XX i początku XXI. Za pośrednictwem analizowanej publikacji można zapoznać się z poezją współczesną w interpretacji Maghiela van Crevela, który jako znany profesor-sinolog opisuje awangardę liryczną ze wszelkimi jej osobliwościami. W swojej pracy opowiada on o źródłach formowania się poezji emigracyjnej. Książka skomponowana jest w taki sposób, że czytelnik może prześledzić nie tylko pozytywne elementy współczesnej poezji, ale także uświadomić sobie kontrowersje wokół tzw. nurtu „poezji mglistej”.

Omawiana w książce Maghiela van Crevela historia obejmuje tematy zakazanej poezji undergroundu czasów Rewolucji Kulturalnej, a także wszystkie etapy transformacji chińskiej awangardy literackiej.

W niniejszym tekście prześledzono stosunek Maghiela van Crevela do wpływu sztuki zachodniej na chińską kulturę i poezję. Bardzo zręcznie wyraża on swoje myśli i wrażenia, odwołując się do poglądów innych badaczy oraz cytując wybitnych chińskich krytyków literackich.

Autor skupia uwagę na poetach, których nie zalicza się do grona kluczowych przedstawicieli awangardy poetyckiej. Pozwala to czytelnikowi zrozumieć, iż poeta jest człowiekiem zwyczajnym, może pisać w prostym języku, używając mowy potocznej jako narzędzia.

Słowa-klucze: Maghiel van Crevel, chińska awangarda, „poezja mglista”, 
Xi Chuan, Han Dong and Yu Jian, Yin Lichuan, Shen Haobo, Yan Jun, "gorączka kulturalna".

\section{Китайская авангардная поэзия времен разума, беспредела и денег в интерпретации Магхела ван Кревела.}

Аннотация: Статья написана в форме рецензии на книгу. В статье рассказывается о китайской авангардной поэзии, как тенденции в литературе 20 столетия - начале 21 столетия. Мы знакомимся с современной поэзией в интерпретации Магхела ван Кревела, который, будучи известным профессором-синологом, описывает лирический авангард со всеми его особенностями. В своей книге автор рассказывает об истоКах формирования эмиграционной поэзии. Книга построена таким образом, что читатель может проследить не только положительные стороны современной поэзии, а также осознать всю противоречивую природу туманной поэзии. Статья вкратце описывает историю современной поэзии. Она охватывает период запрещенной поэзии андеграунда времен культурной революции, а также отображает все этапы трансформации китайского авангарда в литературе. В статье прослеживается отношение Магхела ван Кревела к влиянию западного искусства на китайскую культуру и поэзию. Он умело выражает свои мысли и чувства, используя слова других и цитируя велиКих китайских литературных критиков.

Самым интересным моментом в книге остается то, что автор акцентирует внимание на поэтах, которые не относятся к ключевым представителям поэтического авангарда. Это позволяет читателю понять, что поэт является самым обычным человеком и может писать в простой манере, используя разговорную речь, как средство сближения с народом.

Ключевая цель статьи заключается в том, чтобы стать кратким очерком среды поэтического авангарда, а также предоставить ключи к разгадке причины подобного поэтического эмиграционного творчества.

Ключевые слова: Магхел ван Кревел, китайский авангард, поэзия авангарда, туманная поэзия, Си Чуань, Хань Дун и Юй Цзень, Инь Личуань, Шень Хаобо, Ень Цзюнь, „Культурная лихорадка”. 
Introduction. A great contribution to the world literature has been made by Maghiel van Crevel ${ }^{1}$, a great scientist of Oriental studies, a popular writer and lecturer. He got his $\mathrm{PhD}$ in Chinese Language and Literature in 1996 and devoted all his life and work to the research of Chinese literature.
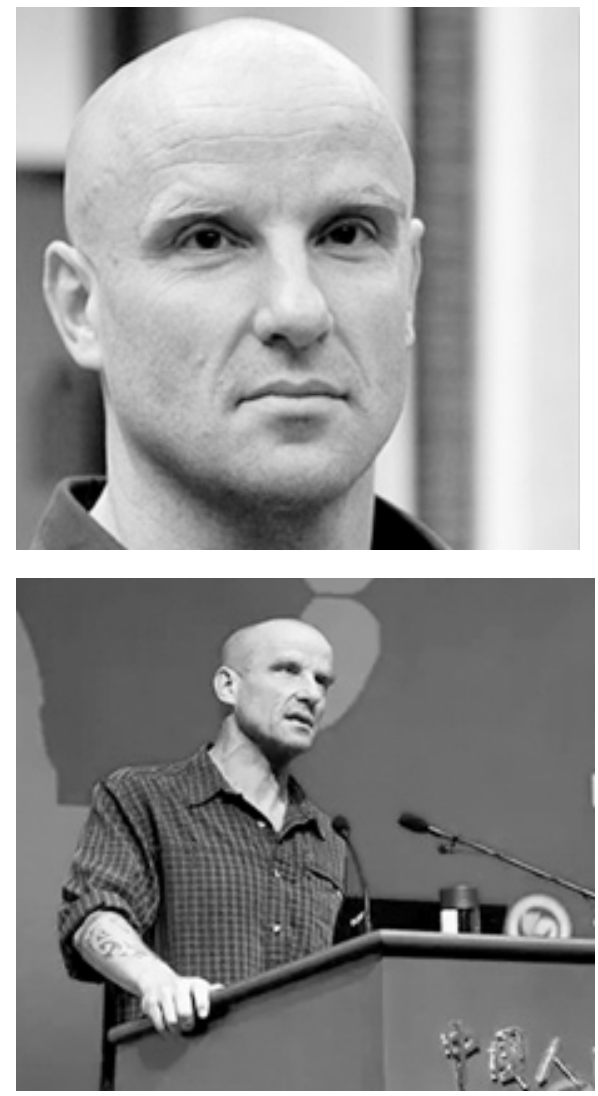

As he wrote about himself: ,My fields of interest include (Chinese) literature and culture, translation, language and language acquisition. My research specialization lies in the contemporary Chinese poetry. There was poetry before there was Chinese - this proposition is defensible as a general claim, and it definitely holds for my personal development as a scholar. I like to think of my research as three-dimensional: text (poems), context (socio-political surroundings) and metatext (discourse on poetry). Building on textual analysis as well as regular fieldwork in China undertaken since 1991, my work also draws on the history, sociology and anthropology of literature and on translation studies" [3].

1 Maghiel van Crevel is a Professor of Chinese Language \& Literature at Leiden University, and an internationally recognized expert on modern Chinese poetry. He has published extensively in English, Dutch and Chinese, for specialist and general audiences. 
Since 1999, when he became a Full Professor of Chinese Language and Literature at Leiden University, his interests have not been only limited to the above-mentioned aspects he has been investigating the intercultural relations with China, including the politics, history and general society issues. Van Crevel has written numerous books and articles on the Chinese culture. This Article attempts to present a critical review of his book „Chinese Poetry in Times of Mind, Mayhem and Money".

In the book under review, van Crevel suggested his own perception of the contemporary Chinese poetry.

Having a great creative skill and experience in writing fundamental works on sinology and Chinese literature, in particular, he aimed to write a book about avant-garde poets in such a way that the book encapsulated almost all the key information about vanguard poets of the $20^{\text {th }}$ century.

The book tells about the history of avant-garde poetry. The author shows the poetry through the eyes of the Chinese and foreign writers and critics, as well as through the eyes of the whole nation born in Celestial Empire.

Yet another interesting peculiarity is that the book, while emphasizing the reception and acceptance of the new poetry, also focuses on its rejection by the reader. The vital role belongs to poetic peculiarities of the vanguard poets' creative style of writing, to literary techniques; to the revealing of narrative strands.

The attention is also focused on the characters and heroes. Via the heroes the reader can see the inner world of an exile-poet and can trace the self-reflection of a poet.

An important thing is the division of the avant-garde lyrics into two parallel aspects, such as: spirituality and material values. The author formulates his research in the way that makes the reader think and give the answer to the question whether we always read pure avant-garde poetry or a mixture of a poetry and prose. The reader gets acquainted with projection of the Chinese text to the content, which is sometimes difficult to understand. Without the knowledge of Chinese conceptual and categorial framework of images and symbols of the Chinese history and traditions it is difficult to interpret the ideas of avant-garde in the poetry.

Description of the book's structure. The book „Chinese Poetry in Times of Mind, Mayhem and Money" gives an impression of a great masterwork 
that causes admiration for the structure of presenting the information: step by step, we can immerse ourselves in the atmosphere of Chinese avant-garde, smoothly „swallowing” each chapter, we can analyse and examine the context. The author greets the reader with „Preface”, in which he explains his avocation to write about contemporary Chinese poetry as an interesting and popular platform of literary material, and he emphasizes that the book must become a logical extension for such famous online studies as: „Unofficial Poetry Journals from the People's Republic of China: A Research Note and an Annotated Bibliography” (2007); ,Avant-Garde Poetry from the People's Republic of China: A Bibliography of Single-Author and Multiple-Author Collections” (2008) and „,Avant-Garde Poetry from the People's Republic of China: A Bibliography of Scholarly and Critical Books in Chinese” (2008), published by means and help of Contemporary Chinese literature and culture resource center [Maghiel van Crevel 2008].

For the convenience of the reader, van Crevel explains the peculiarities of data presentation (including the usage of punctuation in poetry, the determination of the title) in the „Conventions” section. The author expounds on the use of phonetic reading of the poetry with the help of pinyin ${ }^{2}$ (汉语拼音 Hàn y̌u pīn $y \bar{\imath}$ ).

At the beginning of the book there is separate list of illustrative materials („List of Illustrations"). The main text is presented in 518 pages, in thirteen Chapters, each of which provides a detailed information, being divided into several topics. The list of cited works and references to poets, authors and lyrics are completed in alphabetical order.

Statement of the basic material. Like the author of the book, who is a supporter of consistency and structure in his work, we will try to provide a subjective critical material by making a clear and thorough review of each Chapter.

In the First Chapter ,Avant-Garde Poetry from China: Text, Context and Metatext" the author covers six topics. We are supposed to present a brief content of each topic step by step in this article. Within the first topic ,What Went Before" the author makes a journey into the history of Chinese poetry,

2 汉语拼音Pinyin is the most widely-used system of writing Mandarin Chinese that uses the Latin alphabet [6]. 
naming the most popular ancient Chinese poetry collections: 《诗经》 („Shī jīng” - „Shi Jing” or „The Book of Songs”) and 《楚辞》(„Chǔ cí” - „Chu Poetry lines"). Hereafter - he makes a smooth transition to the state and conditions of the poetry in the year of 1911, when the Republic of China emerges with the downfall of the last imperial dynasty, the new leaders Hu Shi and Cheng Duxiu came out and spoke for the literature, written in a simple manner, with a simple language, using modern terminology. All the Chinese literature comes through the way of changes with a new aim and tasks that appear after the Cultural revolution (文学革命wén xué gé mìng) of 1917.

Among the people and in the newspapers of that period the only way of thinking has found its reflection: no classical and traditional Chinese 文言 ${ }^{3}$ wén yán wén for poetry. The poets of the new generation preferred白话文 ${ }^{4}$ bái huà wén. For such a simplification in literature, the author wrote the following: „The classical and the vernacular were not different linguistic registers but distinct languages, as far apart as Latin and present-day French" [Maghiel van Crevel 2008, p. 3]. The poetry of the new time (新诗xīn shī) is defined by the tendency to use neologisms, are mainly formed by foreign linguistic borrowings. A disrespect for traditional classical poetry style is observed among young Chinese poets. The classical poets have lost their prestige among the readers.

For the better understanding of the circumstances and surroundings, the author tells about the social and political issues that made a great influence on the creativity of Chinese poets. This data is presented in the First Chapter of the book. The writers were made to create their poetry in strict accordance with what Chinese Communist Party dictated and with the rules and needs of Chinese Poets' Association (中国作家协会Zhōng guó zuò jiā xié huì). At this very unstable period a new poetry of Social Realism appears (社会主义现实主义shè huì zhǔ

3 Classical Chinese, Classical Chinese (wenyan 文言 or gudai Hanyu 古代漢語 “old Chinese") is the written language that took form during the late WARRING STATES PERIOD 戰國 (5th cent.-221 BCE) and was in use as a written language to the beginning of the 20th century [8].

4 Baihua, baihuawen (白話文), the vernacular literary language as opposed to the Classical literary language wenyan (文言), is closely related to the New Literature Movement (Xin wenxue yundong 新文學運動) and the May Fourth Movement (Wusi yundong 五四運動) in China at the beginning of the 20th century [9]. 
yì xiàn shí zhǔ yì); later, there appeared a mixed type of poetry which combined the revolutionary realism and revolutionary romanticism (革命现实主义和 革 命浪漫主gé mìng xiàn shí zhǔ yì yì hé gé mìng làng màn zhǔ).

Being limited and restricted in the style and topics for writing, being forced to write for the needs of the Chinese Communist Party the poets created a new style, which got its name in the history of literature as „Mao Style”5 (毛文体 máo wén tî̀), being the only possible way of writing nearly until the 1960s. So, only the ideas of the Party and the leader were important.

One of the topics of the book is „The Unofficial Poetry Scene and the Avant-Garde", where the author addresses the subject of Chinese intellectual class (知识青年zhī shi qīng nián), and more specifically - the young poets. They were forced to work on agricultural lands, factories and plants. It was a step of the Communist party to take youth away from social and political problems. The government was afraid of the uprising and the young generation of the poets could easily go against the government, being supported by the people.

In such circumstances the unofficial (非官方fêi guān fāng) poetic stage emerged (诗坛shī tán) in the environment of literary underground (地下dì xià). The author places emphasis on the poets calling themselves as avant-garde (先锋xiān fēng). The avant-garde lyrics of the underground appeared „on the surface" only in 1978, when the first Misty poetry literary journal „Today” (《今天》) was published.

The second topic of the Chapter touches upon the question of the differences between ,publication” of the poetry and the „output or release/circulation”, which can correlate with the Chinese terms 出版chū băn and 发表fā biăo. This means that not each lyrics that is spread among the people and which circulates in the masses may be published [Maghiel van Crevel 2008, p.8].

The vanguard poetry is also associated with the terms: experimental (实验 shí yàn) and research (探索tàn suǒ).

5 Mao Zedong (1893-1976) was one of the most influential and significant individuals in the whole history of China. He was the founder of the People's Republic of China and chairman of the Chinese Communist Party from 1949 until his death. His political ideologies were founded on Marxist and Leninist theories. His strategy of government and military rule was known as Marxism-Leninism-Maoism. This was occasionally shortened to simply "Maoism" or "Mao Zedong Thought" [10]. 
In the third topic of the Chapter „Context: Times of Mind, Mayhem and Money" the author reveals the key words of the name of his book. Thus, „Mind" is associated with the atmosphere of blossom during the period of reforms and changes, which lasted till the summer of 1989. In this period the literature and art, as it is said in the book, spin out of the control of the governing authorities and therefore we can see birth of the epoch of „cultural fever” (文化热wén huà rè). The „Mayhem” is associated with the events of „the fourth of June", which took place on Tiananmen Square. The governmental actions were directed against the riot of the students.

After the mass shooting up, mass human rights abuses, massive repressions and imprisonment of the young talented poets, only some of them continued to express their revolutionary feelings and beliefs in poetry. Most of the Misty poets quitted after the events of 1989 , some of them moved to other countries - escaped by themselves or with their families. The author associates the term „Money" with China of the 1990s, when the poets tried to survive in terms of entertainment industry development, in terms of demand growth, new media, marketing development, i.e. - under the terms and conditions of transition to the money-oriented relations in all spheres of life, including literature and art [Maghiel van Crevel 2008, p. 14].

Poetry of these years was focused mainly on Western ideas, so for the new tendency in the literary circles the term „Western” (西方xī fāng) art was used. In this topic the author tells about the Misty poets (朦胧诗méng lóng shī) of the second half of the $20^{\text {th }}$ century.

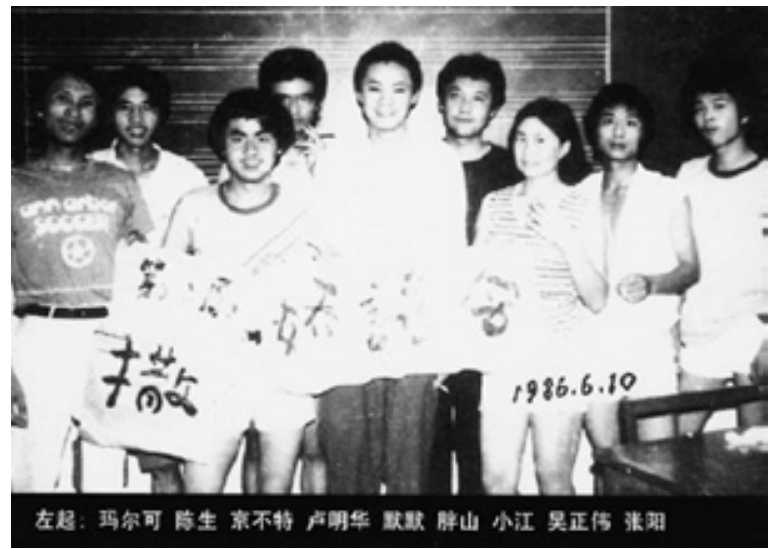

The picture of young Misty poets 
The author noticed that even though the Misty poets were associated with Peking (Beijing - the capital of the People's Republic of China) and the journal „Today” ( 《今天》 / 《Jīn tiān》), the poetry spread all over China and reached other countries. Moreover, the Misty poetry covered many poetic groups, styles and frames of mind.

The Second Chapter „True Disbelief: Han Dong” tells us about the creative poetic art of Han Dong. The Third Chapter „Thanatography and the Poetic Voice: Hai Zi" reveals the live aspects and poetry of the young avantgarde poet Hai Zi. The Fourth Chapter „Exile: Yang Lian, Wang Jiaxin and Bei Dao" tells about the poets in exile.

The key terms and words of the literary period of $80 \mathrm{~s}-90 \mathrm{~s}$ of the $20^{\text {th }}$ century is the following:

流亡 (liú wáng) - to run away, to escape, refugee, escapee;

放逐 (fàng zhú) - to outlaw, to exile, to deport, to send into exile;

流放 (liú fàng) - to relegate, to deport, to exile;

流散 (liú sàn) - to stroll, live a vagabond life;

离散 (lí sàn) - to go off in contrary directions;

漂流 (piāo liú) - to stroll, wander about;

漂泊 (piāo bó) - vagabond, be on the tramp;

海外 (hăi wài) - beyond the sea, overseas (the Chinese word is used to define people in exile);

异乡(yì xiāng) - foreign land, foreign country, alien land, outland.

These words appear in all newspapers, journals, magazines and critical essays.

The author gives the names of poets who continued their creative writing being abroad and living in exile, e.g. Yang Lian, Do Do, Bei Dao, Sue Di, Hu Dong, and others. The names of these avant-garde poets almost always are associated with ,Today” (《今天》/ 《Jīn tiān》).

The author starts the Fifth Chapter „Mind over Matter, Matter over Mind: Xi Chuan" with representing the art of one of the most popular poets of the lyrical avant-garde - Xi Chuan, who started to write poems at the end of the 1990s. His art of writing was later dubbed „西川体” (Xī Chuān tĩ) - „the style of Xi Chuan”. In the Chapters 6-13 the author often addresses the name of Xi Chuan. The Sixth Chapter „Fringe Poetry, But Not Prose: Xi Chuan and Yu Jian" touches upon the question of prose poems. Here 
Maghiel van Crevel tried to separate poetry from prose in the writing of avant-garde poets.

Chapter 7, „Objectification and the long-short line: Yu Jian” is dedicated to the poet Yu Jian, who wrote in the period of the 1990s. His poems were translated into English, French, Italian, Spanish and other languages. Yu Jian is a striking personality on the stage of avant-garde poetry. He represented his poems in a manner of a typical colloquial language, he described the life of people as it is in reality. For all his manner of presenting the poetry was used the term ,日常主义” (rì cháng zhǔ yì) - meaning „daily life, everyday routine" [Maghiel van Crevel 2008, p. 252]. All the art of Yu Jian is similar to the creative art of Bei Dao and Mang Ke. The style of writing used by Yu Jian is also called ,长短句” (cháng duăn jù) - „long and short sentences”. Importantly, the term does not cover Chinese poetic genre 词 cí [Maghiel van Crevel 2008, p. 274].

The style is characterized by the absence of punctuation marks, instead the long intervals were made. The intervals were much bigger than the Chinese character itself, as in the following example:

\section{十一点整 这是通常分手的时间 规距 大家都要睡觉}

雨是次要的 再大的雨 都要回家 走掉了 [Maghiel van Crevel 2008, p. 275]

It is eleven o'clock it is a typical time for farewell as a rule

All the people retire for the night drizzling rain again a heavy fall of rain everyone needs to come back we are getting away

\section{Chapter 8, „Narrative Rhythm, Sound and Sense: Sun Wenbo" di-} scusses the peculiarities of the vanguard lyrics style. Chapter 9, ,The Lower Body: Yin Lichuan and Shen Haobo" provides information about the vanguard group of poets called the „Lower Body” (,下半身” „xià bàn shēn”). It appeared at the beginning of the $21^{\text {st }}$ century. One of the brightest representatives is Yin Lichuan with her famous poem, ,为什么不再舒服一些” (,Why not to repeat in a more convenient way"). Maghiel van Crevel speaks of the intimate lyrics written by Yin Lichuan as of the quite atypical phenomenon in the Chinese literature. It has no restrictions, no rules, it uses low-minded words and vulgar terminology. Even the most modern and revolutionary-oriented poets could not accept her writing. She was not alone to compose „Lower Body” 
poems, Shen Haobo was among those poets who presented the dark side of human nature. And yet, even the rude voice of the „Lower Body” poets got a large audience of readers abroad.

Chapter 10, „Not at Face Value: Xi Chuan's Explicit Poetics” concentrates on the art of Xi Chuan and his rules with guidelines which he gives to each Chinese contemporary poet. Chapter 11, „Desecrations? Han Dong's and Yu Jian's Explicit Poetics" presents the two key and famous Chinese poets, literary critics - Han Dong and Yu Jian, who embody the desacralization of tragedy and heroism of the Misty Poetry movement of the 70s-80s of the $20^{\text {th }}$ century. The creators Yu Jian and Han Dong made the anti-cult of the whole Misty Poetry, tracing its history from 1980s to 2000s. The Chinese critics acknowledge the superiority of the poetry in history, but they put the poet on the same stage with the Holy One, in his immortal masterpieces. The author provides a range of Han Dong's quotations from the book „After the three world-roles” (《三个世俗角色之后》, 1989). The critics thought that the difference between the Eternal, as a creator of the World, and the Poet, as a writer, is in the following: the Holy One needed only six days to create the World (and the seventh day was left for rest), but the Poet needs the whole life to create a good anthology of poetry. Yu Jian continued this idea in the book „The revival of the poetry spirit” (《重建诗歌精神》, 1989), insisting that the poet should not be a spiritual advisor or the missionary, as this is the role of the Holy One. The role of a Poet is to become a friend to the reader, to share own life experience [Maghiel van Crevel 2008, p. 369]. Han Dong and Yu Jian give preference to write about common people, they insist on that a man cannot be ideal. They try to persuade the reader that a poet must use a colloquial speech with dialects to show real world as it is. Using dialects in the modern poetry becomes a very prospective manner of writing at the turn of the $20^{\text {th }}$ and the $21^{\text {st }}$ centuries.

On the other hand, modern style of writing does not prevent Yu Jian and Han Dong from criticizing those avant-garde poets who neglect and do not respect the old traditions of Classical Chinese poetry.

The book tells about the disrespect of Yu Jian towards the Chinese poets who moved abroad: ,... they consider it an honor to be in exile in Europe and America, they will scramble to get in and worry about being left out. Why don't they go into exile in Vietnam, or Burma, or Tunisia? Taking pride in 
exile shows that deep down, their mindset is that of colonized men of culture" [Maghiel van Crevel 2008, p. 385]. In such a way Yu Jian shows that it was not an exile at all, but the way to live in Europe, to have a better life, to escape from reality.

Chapter 12, „What was all the fuss about? The popular intellectual polemic" focuses on the question of polemic (论争) relating to popular writing (民间写作) and intellectual writing (知识分子写作) in avant-garde sphere. Maghiel van Crevel points out the dominance of masculine text of the Misty poetry style. The Chapter comprises the review of critical articles, books, devoted to the Chinese poetry of 1990s. On the one hand, Chapter 13, „More than writing, as we speak: Yan Jun" is like a closure and summary of the book, while on the other - it is like a key chapter telling about the modern Chinese poetry of the 1990s and early 2000s. Here the author describes the art of writing of the Chinese poet, critic and editor Yan Jun. The book presents new approaches to the art of poetic style.

Conclusions. The book „Chinese Poetry in Times of Mind, Mayhem and Money" written and ingeniously composed by Maghiel van Crevel became a real treasure among the Oriental literature critical works and may be considered to be a real masterpiece of the contemporary literature. It comprises all the aspects and details, revealing the history, peculiarities and personalities of the Misty vanguard poetry. The Chinese Misty poetry started nearly a century ago, it will last for quite a long period of time and the key reason for this is the tendency of positive and negative transformations, which put the literature on the stage of internationalization and adopting the Western poetic style.

\section{Bibliografia}

Maghiel van Crevel (2008). Chinese Poetry in Times of Mind, Mayhem and Money. Leiden: Brill. - $518 \mathrm{p}$.

(Chinese Poetry in Times of Mind, Mayhem, and Money (free download), Leiden: Brill, 2008, with a Chinese citations supplement (ibid), MCLC resource center, 2017; translated as Jingshen yu jinqian shidai de Zhongguo shige: cong 1980 
niandai dao 21 shiji chu by Zhang Xiaohong in collaboration with the author, Beijing: Peking University Press, 2017.

Hao Lin \& Yingying Huang (Translator) (2019). The Text and the Extra-Textual: Dutch Sinologist Maghiel van Crevel and His Research on Contemporary Chinese Poetry, Chinese Literature Today, 8:1, 124-126, DOI:10.1080/21514399.2019.1605268

Internet resource: https://www.universiteitleiden.nl/en/staffmembers/maghiel-vancrevel\#tab-2

Internet resource: https://www.revolvy.com/page/Lower-Body-Poets

Internet resource: https://paper-republic.org/translators/van-crevel-maghiel/

Internet resource about the pinyin alphabet: http://www.bbc.co.uk/languages/chinese/real_chinese/mini_guides/pinyin/

Internet resource: http://www.hwjyw.com/zhwh/Common_Knowledge/China_culture/200902/t20090223_27062.shtml

Internet resource about classical Chinese language: http://www.chinaknowledge. de/Literature/Script/wenyan.html

Táňa Dluhošová. Baihuawen: Its Origins and Significance. Institute of East Asian Studies, Charles University. P. 1-13.

Internet resource and the article: https://www.soas.ac.uk/taiwanstudies/eats/ eats2008/file43158.pdf

Internet resource: https://mypoeticside.com/poets/mao-zedong-poems

Internet resource: http://www.chinaknowledge.de/Literature/Poetry/songci.html

Dave Haysom. What is Chinese 'Lower Body Poetry'? An article, printed on the $26^{\text {th }}$ of October 2017 at www.poetrytranslation.org.

Internet resource: https://www.poetrytranslation.org/articles/what-is-lower-halfbody-poetry 